\title{
Participative Management, Collective Bargaining, and Professionalism
}

\begin{abstract}
This paper attempts to analyze participative management and collective bargaining as strategies for attaining certain goals. A distinction is drawn between those goals (needs) which all employees have in common and those which characterize only professional workers. The effectiveness of each strategy is then discussed, with examples taken from professions other than librarianship.
\end{abstract}

I AN EDITORIAL appearing in College \& Research Libraries, Richard DeGennaro stated:

One of the legacies of the protest movement of the last several years has been a certain restlessness and searching on the part of librarians for a greater role in the decision-making process in their libraries and a voice in the conditions of their employment. Two powerful ideas and trends have begun to emerge out of this confused and stressful situation: participative management and unionization. ${ }^{1}$

Since this editorial appeared, a considerable amount of library literature has been devoted to these two topics. But despite the wealth of literature, very little effort seems to have been devoted to relating the two ideas. The question that needs to be addressed is not how to achieve participative management (or neutralize staff interest in unionization), but why are professionals interested at all in participative management or collective bargaining.

Some of the literature on this topic would seem to suggest that participative

Thomas W. Shaughnessy is Associate Dean, School of Library Science, University of Southern California, Los Angeles.

management is an end in itself, and that in some cases collective bargaining through unionization is a means (of last resort?) of attaining that goal. If we accept this view, however, we are faced with having to explain the fact that participative management existed long before the unionization of professional employees, that collective bargaining is a phenomenon that historically addressed economic issues as distinguished from managerial and policy questions, and that collective bargaining inevitably sharpens the distinction between labor and management and places this relationship in an adversary context.

Then there is the concern which has been expressed by a few academic librarians that participative management may have adverse effects on the quality of service delivery inasmuch as the productivity of professional staff may decrease due to the proportion of time spent participating through committees, task forces, and strategy groups. ${ }^{2}$

It is the hypothesis of this paper that among professional staff neither participative management nor collective bargaining is an end in itself, but that these are mechanisms for attaining certain goals which are basic to all professions. 


\section{EMPlOyee NeEdS AND GOALS}

To a certain extent all employees, regardless of their positions, hold in common certain objectives and needs. These were first described by Maslow and then elaborated upon by McGregor. ${ }^{3,4}$ But professionals are distinguished from other workers by the intensity with which they seek to satisfy certain of these needs, by the particular mix of work-related values that will provide optimum satisfaction, and by the hierarchy of these needs.

In general, professionals as a group have a stronger attachment to their work and expect to derive more from it than do non-professionals. For most professionals, work is more than just a job. Consequently, it is possible to distinguish between the goals that professionals seek to achieve in their jobs and careers and those of other workers. ${ }^{5}$

Kleingartner, in a study conducted in 1967, distinguished between Level I and Level II goals. ${ }^{6}$ Level I goals may be defined as those relating to fairly shortterm job rewards such as wages or salaries, working conditions, fair treatment, fringe benefits, and some measure of job security. These are the issues typically addressed by the collective bargaining process. These bread and butter issues are common to all categories of workers, regardless of education, function, or status.

Level II goals, in contrast, may be defined as longer term professional goals. They are not generally held by non-professionals as realistically attainable objectives. But for professionals, these goals are centrally related to the content and mission of the functions performed by the various professions. It is interesting to note that these goals rarely become concrete issues or objectives until Level I goals are adequately met.

Much of the substance of Level II goals can be encompassed by the concepts of (1) professional autonomy, or the right to determine how a function is to be performed; (2) professional integrity and identification, as distinguished from loyalty to institutional or organizational structures; (3) individual satisfaction and career development, including control over decisions affecting one's work and career; and (4) economic security and enhancement, that is, rewards should reflect not so much the contribution made to the employing organization directly, but the quality of service rendered. ${ }^{7}$

It is important to note that the attainment of these objectives would give professionals a real, as distinguished from symbolic, voice in determining some of the policies of the organizations in which they work.

\section{Participative Management}

If it is true that librarians and members of other professions aspire by reason of their status to achieve Level II goals, what are the means which have been successfully used to attain them? Non-professional workers have typically attempted to achieve their objectives through either collective bargaining or legislation. Despite the fact that the unionization of professionals has been a fairly recent occurrence, there is considerable evidence that collective bargaining can be used to achieve Level II goals as well. The use of other strategies to achieve these ends, such as legislative processes and lobbying, has a much longer history.

But in addition to these tactics, professionals have available to themselves at least two other means: professional standards and participative management. ${ }^{8}$ It would be impossible within the scope of this paper to discuss all of these strategies. The attempt to use standards of professional service (which theoretically at least should define the quality of service to be provided to society) to achieve self-serving, profession-directed objectives is an extremely interesting phenomenon which appears 
to have special relevance to librarianship. However, this strategy, along with legislative processes, will not be discussed here.

As a mechanism for achieving Level II goals, participative management would appear to be the more attractive strategy for librarians. There are several obvious as well as subtle arguments to support this view.

The first is that it is the professionalism of an individual which is more important than his or her office in an organization. In other words, all librarians, regardless of rank, have a harmony of interests, a service ideal, a fundamental identity. This would appear to be a basic assumption of the American Library Association. As is the case with many other professional organizations, the ALA has fostered an attitude of cooperation between employer and employee. According to this view, improved communication, consultation, and education of its members through association programs work to solidify and strengthen the bonds of common concern. ${ }^{9}$ That this is also a typical management view should not be surprising if one considers the fact that ALA leadership posts are so often filled by library administrators.

Undoubtedly, most librarians and library administrators would agree that fundamentally they share responsibility for developing the field of librarianship and for providing effective service. However, many employers and administrators have used the concept of harmony of interests as a basis for attacking efforts of salaried professionals to organize. This tactic mistakenly tends to equate professionalism with loyalty to management. ${ }^{10}$ At the very least, it implies that librarians who attempt to bargain collectively are acting unprofessionally.

A second advantage that participative management has over collective bargain- ing as a goal attainment strategy is the notion that it increases both staff morale and productivity. ${ }^{11}$ It would appear that the Association of Research Libraries' Management Review and Analysis Program is based at least in part on this assumption.12 Evidence does indeed exist which supports the relationship between participative management and job satisfaction. ${ }^{13}$ The influence of participative management on productivity, however, is far less certain. ${ }^{14}$

A third, but not widely recognized, advantage of participative management is that it facilitates both the socialization of professionals who are insuffciently normative and the co-optation of those who either have leadership qualities and/or professional loyalties which are greater than their institutional allegiances. For the upwardly mobile, cosmopolitan professionals, ${ }^{15}$ participative management is a much more palatable means of achieving Level II goals than is collective bargaining. Indeed, to the extent that professionals allow themselves to be co-opted (hereby winning the approval of superiors and possibly recognition within informal power networks), the more rapidly will they rise through the ranks and achieve not only their professional goals but greater economic benefits (Level I goals) as well.

Participative management as a strategy is further enhanced by its reliance upon the academic or collegial model with its attendant committee structure. Organized as a community of scholars, college and university faculty dominate educational policy matters and, in many instances, exert a major influence on college organizational structure.16 For the most part, however, libraries are organized as hierarchical, bureaucratic structures which would have to undergo radical change if they were to completely adopt the collegial model. ${ }^{17}$ The organizational stresses and strains which 
occur when collegial approaches are introduced into hierarchical structures have been partially described by McAnally and Downs. ${ }^{18}$

One of the characteristics of the academic model-the ubiquitous committee-has been used as a mechanism for providing opportunities for participative management. But there is an important distinction between consultative and advisory processes on the one hand and actual decision-making processes on the other. The committee structure facilitates the achievement of the former, but attainment of Level II goals would seem to require the latter.

\section{Collective Bargaining}

A second strategy for achieving Level II goals is collective bargaining. The moral, legal, or professional aspects of the unionization of professionals would appear to be a dead issue. Physicians have formed unions (and have actually gone on strike); $;{ }^{19}$ lawyers have formed unions; ${ }^{20}$ and many teachers, ${ }^{21}$ social workers, ${ }^{22}$ and nurses ${ }^{23}$ are also members of various unions. Consequently, it will be assumed that collective bargaining is an appropriate strategy for librarians as well.

Historically, labor unions have been primarily concerned with improving the economic status of their members. Frequently economic issues will also be of concern to organized salaried professionals, at least in the early stages of the employee-employer relationship. However the logic of professionalism will not allow a union to ignore for long the Level II goals of its members. The more professional the orientation of the occupation involved, the sooner it will begin focusing on Level II types of concerns. ${ }^{24}$

Whereas participative management has a number of advantages from an organizational viewpoint as well as from that of the upwardly mobile, in- dividual professional, collective bargaining from the outset establishes an adversary relationship between labor and management. In participative management, management permits employees to share gradually in management prerogatives and power, but in collective bargaining the employees decide to share in certain decision-making processes, regardless of management's attitude or posture. The latter is a power relationship. The resolution of differences between union and management rests on the balance of the relative bargaining powers of the two parties. This power aspect of industrial relations is both fundamental and inescapable. ${ }^{25}$

For librarians and members of other professions and semi-professions, collective bargaining raises a number of important questions. First, how will the bargaining unit be determined? Will it be comprised of librarians only? If the answer is affirmative, then one must consider whether there are a sufficient number of librarians in the unit to be effective. Frequently, librarians work within a larger, heteronomous organizational setting and do not constitute either a large number or percentage of the employees. As a result, in some universities librarians find themselves grouped with teaching faculty; in public libraries, sometimes with other library personnel. In such situations, it may be difficult for librarians to achieve those goals which are derived primarily from their own professionalism.

Perhaps librarians who find themselves in this situation view collective bargaining as a device not for achieving their Level II goals, but for merely achieving some degree of participative management. It is questionable, however, whether this is a viable objective. It seems likely that collective bargaining would polarize labor and management, and thereby reduce opportunities for professionals in decision-making processes. 


\section{4 / College \& Research Libraries • March 1977}

\section{Collective Bargaining in Related Professions}

Related to these concerns is a second major question which must be resolved; namely, what is the proper scope of bargaining for professional employees? Scope of bargaining is defined in legislation regulating the collective bargaining process. The National Labor Relations Act speaks of bargaining "with respect to wages, hours, and other terms and conditions of employment."26 Legislation which confers upon public employees the right to bargain generally contains similar language. ${ }^{27}$ For many professionals the phrase, "terms and conditions of employment," has been translated into policy-making power over all professional practice..$^{28}$

For example, the National Education Association's position is as follows:
A professional group has responsibili- ties beyond self-interest, including a responsibility for the general welfare of the school system. Teachers and other members of the professional staff have an interest in the conditions which attract and retain a superior teaching force, in in-service training programs, in class size, in the selection of textbooks, and in other matters which go far beyond those which would be included in a narrow defini- tion of working conditions. Negotia- tions should include all matters which affect the quality of the educational system. ${ }^{29}$

Under this broad definition of scope of bargaining, teachers would appear to have the right to negotiate issues which might properly be called matters of educational policy. And insofar as matters of educational policy directly relate to the mission and function of the teaching profession, they constitute Level II goals.

Members of the nursing profession are also turning to collective bargaining as a means for achieving their professional goals. For example, the 1974 San Francisco nurses strike may have estab- lished a precedent in hospital labor relations because it was the first time that "matters of patient care and nursing performance took priority over matters of a strictly financial or economic nature." ${ }^{30}$ This episode may have great significance for nurses inasmuch as the scope of bargaining has been broadened to include issues once thought to be non-negotiable, such as staffing and quality of patient care.

Professionals working in other human service industries are also attempting to influence decisions affecting the nature and quality of services provided. The curators of New York's Museum of Modern Art went on strike because, among other things, they objected to a reduction in the number of annual exhibits. ${ }^{31}$ New York's social service employees negotiated the improvement of welfare services to clients as well as a 25 percent increase in welfare benefits. ${ }^{32}$ And social workers in Los Angeles County successfully negotiated a reduction in case loads, contending that such a reduction would result in improved professional services. ${ }^{33}$

Examples could also be drawn from the medical and legal professions to illustrate the same trend-the use of collective bargaining by professionals to attain professional goals. But the examples presented from the fields of education, social work, and nursing are especially relevant to librarianship. All might be categorized as semi-professions; none has full professional status. Most practitioners in these fields work in organizational settings; they are not as independent or autonomous as those with full professional status. And in all of these fields, women would seem to comprise the majority of the practitioners.

Admittedly, librarianship differs from these fields in a number of significant respects: for example, the range in types of librarians, the structure of the field's professional organization, the difficulty in defining and measuring the product 
or services rendered. Then there is the possibility that perhaps librarians are already achieving their professional goals without resorting to the strategy of collective bargaining. This is, of course, a possibility, but it is very unlikely in view of the fact that, first, it is very difficult to document specific examples of such achievement outside the collective bargaining framework, and, secondly, the bureaucratization of library services would appear to inhibit rather than facilitate the achievement of Level II goals. ${ }^{34}$

The issues raised here are extremely complex, and do not permit easy resolu- tion. The existence of state legislation concerning public employees, the influence of civil service regulations, the differences deriving from public sector versus private sector employment, and the potential role of state and regional library associations are important and very relevant issues which have not been addressed. What has been suggested is that the two major strategies have not been equally effective in achieving professional goals and that both approaches, even when effective, may be accompanied by unanticipated and sometimes dysfunctional side effects.

\section{REFERENCES}

1. Richard DeGennaro, "Participative Management or Unionization?" College \& Research Libraries 33:173 (May 1972).

2. Beverly P. Lynch, "Organizational Structure and the Academic Library," Illinois Libraries 56:201 (March 1974).

3. A. H. Maslow, "A Theory of Human Motivation," Psychological Review 50:370-96 (July 1943).

4. Douglas McGregor, "The Human Side of Enterprise," in V. H. Vroom and E. L. Aece, eds., Management and Motivation (New York: Penguin, 1970).

5. Archie Kleingartner, "Collective Bargaining between Salaried Professionals and Public Sector Management," Public Administration Review 33:166 (March/April 1973).

6. Archie Kleingartner, Professionalism and Salaried Worker Organization (Madison, Wis.: Industrial Relations Research Institute, Univ. of Wisconsin, 1967).

7. Kleingartner, "Collective Bargaining," p.167.

8. Participative management is defined as a mental and emotional involvement of a person in a group situation which encourages him or her to contribute to group goals and to share responsibility in them. It suggests ego involvement as distinguished from mere task involvement. See Keith Davis, Human Relations at Work: The Dynamics of Organizational Behavior (New York: McGraw-Hill, 1967), p.128.

9. Archie Kleingartner and Jean R. Kennelly, "Employee Relations in Libraries: The
Current Scene," in Allerton Park Institute, 20th, 1974, Collective Bargaining in Libraries, edited by Frederick A. Schlipf (Urbana-Champaign: Univ. of Illinois, Graduate School of Library Science, 1975), p.8-10.

10. Ibid., p.7.

-11. Maurice P. Marchant, "Participative Management as Related to Personnel Development," Library Trends 20:48-59 (July 1971).

12. Duane Webster, "The Management Review and Analysis Program: An Assisted SelfStudy to Secure Constructive Change in the Management of Research Libraries," College \& Research Libraries 35:114-25 (March 1974).

13. Davis, Human Relations at Work, p.134.

-14. Beverly P. Lynch, "Participative Management in Relation to Library Effectiveness," College \& Research Libraries 33:382-90 (Sept. 1972).

15. Alvin W. Gouldner, "Cosmopolitans and Locals: Toward an Analysis of Latent Social Roles," Administrative Science Quarterly 2:281-306 (Dec. 1957).

16. Joseph Garbarino, "Professional Negotiations in Education," Industrial Relations 7: 99 (Feb. 1968).

17. H. William Axford, "An Overlooked Cost of Achieving a Participatory Environment," College \& Research Libraries 35:5-6 (Jan. 1974).

18. Arthur M. McAnally and Robert B. Downs, "The Changing Role of Directors of University Libraries," College \& Research Li- 
braries 34:103-25 (March 1973).

19. John Kralewski, "Collective Bargaining among Professional Employees," Hospital Administration 19:30-41 (Summer 1974).

20. "The Unionization of Attorneys," Columbia Law Review 71:100-17 (Jan. 1971).

21. William R. Hazard, "Collective Bargaining and School Governance," Southwestern University Law Review 5:83-117 (Spring 1973).

22. Jerome Lefkowitz, "Unionism in the $\mathrm{Hu}$ man Service Industries," Albany Law Review 36:603-31 (Winter 1972).

23. Ada Jacox, "Collective Action and Control of Practice by Professionals," Nursing Forum 10:239-57 (1971).

24. Kleingartner, "Collective Bargaining," p.169.

25. Michael H. Moskow, Teachers and Unions (Philadelphia: Univ. of Pennsylvania, Wharton School of Finance and Commerce, Industrial Research Unit, 1966), p.193.

26. Labor Management Relations Act, 1947, 8(d), 29 U.S.C. and 158(d), 1964.

27. "Collective Bargaining and the Professional
Employee," Columbia Law Review 69:279 (Feb. 1969).

28. Myron Lieberman and Michael H. Moskow, Collective Negotiations for Teachers (Chicago: Rand McNally, 1966), p.221-47.

29. National Education Association, Guidelines for Professional Negotiation (Washington, D.C.: National Education Association, 1965), p.21-22.

30. Donald F. Phillips, "New Demands of Nurses," Hospitals 48:32 (Aug. 16, 1974).

31. Lefkowitz, "Unionization in the Human Service Industries," p.616-22.

32. Ibid., p.614-15.

33. County of Los Angeles, Los Angeles County Department of Public Social Services, et al., v. Los Angeles County Employees Association, SEIU Local 660, et al. $33 \mathrm{Cal}$. App. 3d 1 (1973).

34. W. Richard Scott, "Professionals in Bureaucracies: Areas of Conflict," in Howard M. Vollmer and D. W. Mills, eds., Professionalization (Englewood Cliffs, N.J.: Prentice-Hall, 1966). 